TAPROBANICA, ISSN 1800-427X. May, 2021. Vol. 10, No. 01: pp. 71-78, pl. 16.

(C) Research Center for Climate Change and Department of Biology, Faculty of Mathematics \& Natural Sciences, University of Indonesia, Depok 16424, INDONESIA.

http://www.taprobanica.org

https://doi.org/10.47605/tapro.v10i1.253

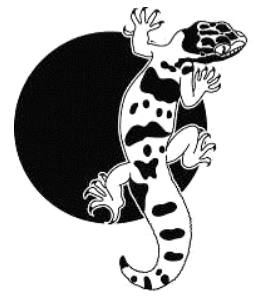

\section{On large colonies of rufous horseshoe bats (Rhinolophus rouxii), western Sri Lanka}

Rhinolophus rouxii and Hipposideros speoris are small-sized bats belonging to the Rhinolophidae and Hipposideridae families, respectively (Phillips 1935). Rhinolophus rouxii is widely distributed in Sri Lanka, India, Nepal, China and Vietnam (Borissenko \& Kruskop 2003, Yapa 2017, Wilson \& Mittermeier 2019), whereas H. speoris is found in Sri Lanka, India and more recently reported from Myanmar (Yapa 2017, Dar et al. 2018, Wilson \& Mittermeier 2019). These two species are listed as of Least Concern in both Global and National Red Lists of IUCN (IUCN-MOE 2012). As per the existing distribution records, they are commonly found in the low country: $R$. rouxii up to an elevation of $1,590 \mathrm{~m}$, whereas $H$. speoris is at altitudes ranging up to $1,385 \mathrm{~m}$ (Phillips 1935, Molur et al. 2002, Yapa \& Ratnavira 2013, Kusuminda et al. 2013, Kusuminda et al. 2018, Wilson \& Mittermeier 2019).

Observations on population size at two large permanent roosting sites of $R$. rouxii from Hapitigama and Hapitigamkanda and a new site records for $H$. speoris from Hapitigama, Gampaha District, Western province, Sri Lanka (Fig. 1) are reported and analysed here, and in doing so we highlight the significance of abandoned graphite mines for sustaining bat populations. The locality falls within lowland tropical rainforest vegetation (Gunatilleke \& Gunatilleke 1990). The annual mean precipitation in 2019 for the nearest meteorological station of Pasyala was $259 \mathrm{~mm}$ (highest $=714 \mathrm{~mm}$, lowest=67 mm] (Department of Meteorology, Sri Lanka). A field visit was conducted on 17 January 2021 from 08:56 h to 14:40 h. Both roosting sites were identified as a result of an inquiry carried out in the locality. Bats encountered in the sites were caught using hand nets (depth: $45 \mathrm{~cm}$, diameter: $30 \mathrm{~cm}$, mesh size: $1.5 \times 1.5 \mathrm{~mm}$ ). Identification to species was done based on Phillips (1935), Corbet \& Hill (1992), Bates \& Harrison (1997) and Sirinivasulu et al. (2010). External measurements of 11 variables (Tables 1,2) were taken following Sirinivasulu et al. (2010) with an Incco-RD10 digital caliper to the nearest 0.1 $\mathrm{mm}$, and weight with a precision digital scale $(0.01 \times 500 \mathrm{~g})$.

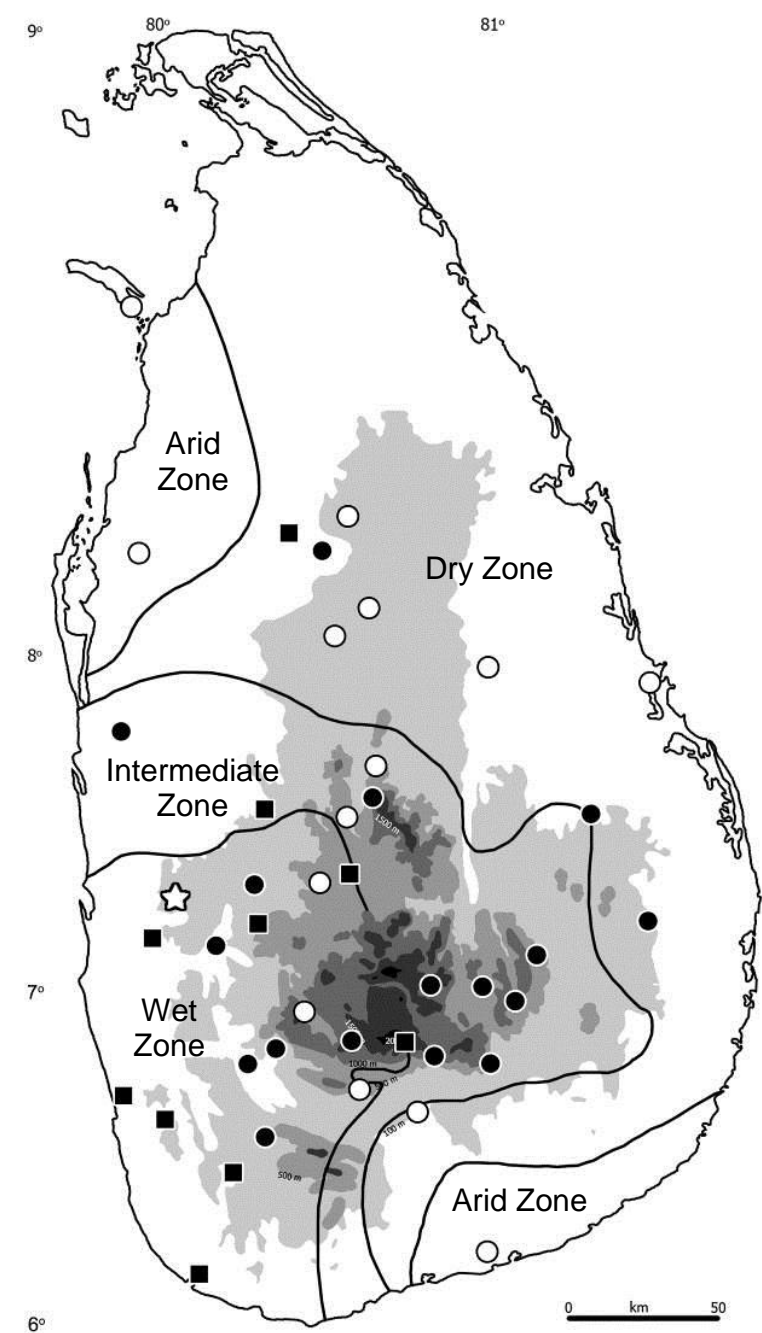

Figure 1. Distribution of Rhinolophus rouxii (filled circles) and Hipposideros speoris (open circles) in Sri Lanka; the localities where both species have been reported together (sympatric) in squares; the present study site is indicated with a star; Historical locations are based on Phillips 1935, Molur et al. 2002, Yapa \& Ratnavira 2013, Kusuminda et al. 2013, and Kusuminda et al. 2018; Map @: A.A.T. Amarasinghe 
Captured bats were kept in cotton bags until the measurements were taken. Morphological characters were documented before the bats were released at the capture site. Ambient temperature and relative humidity were measured using a KTJ- TA 38 digital memory thermo-hygrometer and velocity of the wind by a MS-6252 digital anemometer. Roost surface temperature and body temperature of species found were measured with a Work zone-JHK 6606 Digital infra-red thermometer. Light intensity of the microhabitats was measured using a Digitech-QM 157 light meter. Length measurements of the roosting sites and the ambient surroundings were taken using a BOSCH-GLM-100C digital tape and a meter tape. Geographical coordinates and altitude of roosting sites were determined from readings from a Garmin-Etrex hand-held GPS receiver. Photographs of bats and their microhabitats were taken by a Canon-60D camera with Canon 75 $300 \mathrm{~mm} \mathrm{f} / 4-5.6$ and $18-55 \mathrm{~mm} \mathrm{f} / 3.5-5.6$ lenses.

The size of each colony was studied using an incremental visual encounter method and photographic count method following the standard methodologies of Thomas et al. (1979) and Thomas \& Laval (1988). Visual counts were made by the authors using red filtered head lamps for minimal disturbance, with coordinated efforts and a reasonable amount of time in order to ascertain the accuracy of the colony size and the abundance of species. Sunrise and sunset times on the date of study were recorded as 6.27 $\mathrm{h}(\mathrm{GMT}+5.30)$ and $18.12 \mathrm{~h}$ (GMT +5.30) respectively. Lunar phase was a waxing crescent $(21.3 \%)$ moon. Both study sites were abandoned graphite mines located within a geographical distance of $500 \mathrm{~m}$ from each other.

Study site A: $\left(7^{\circ} 12^{\prime} 06.2^{\prime \prime} \mathrm{N}, 80^{\circ} 07^{\prime} 36.5^{\prime \prime} \mathrm{E}\right)$ a mine situated in an old rubber plantation alongside a $1.8 \mathrm{~m}$ wide concrete road, close to human habitation with two prominent entrances (see Entrance 1 and 2 in Fig. 2). The canopy cover near Entrance 1 was $60 \%$ (11 m in height), dominated by rubber (Hevea brasiliensis), kitul palm (Caryota urens), coconut (Cocos nucifera) and areca palm (Areca catechu) trees.

Entrance 1 (alt. $122 \mathrm{~m}$ a.s.l.) was an eight meter long horizontal tunnel which connects to the main chamber of the mine ( $\mathrm{X}$ in Fig. 2) with a $1.6 \times 0.9 \mathrm{~m}$ sized opening (Fig. 3A). Even though the entire tunnel area was covered by approximately $0.5 \mathrm{~m}$ of water, it was easily accessible by humans. According to the locals, the water body is generated from a natural spring located underneath Entrance 1 of the mine. During the time of observation (08:56 $\mathrm{h})$ ambient air temperature was $26^{\circ} \mathrm{C}\left(\min 26^{\circ} \mathrm{C}\right.$, $\max 26.7^{\circ} \mathrm{C}$ ) and relative humidity was $82.1 \%$ (min $79 \%, \max 84 \%$ ), velocity of wind was recorded as $0 \mathrm{~km} / \mathrm{h}$ and the light intensity was 19267.4 lux.

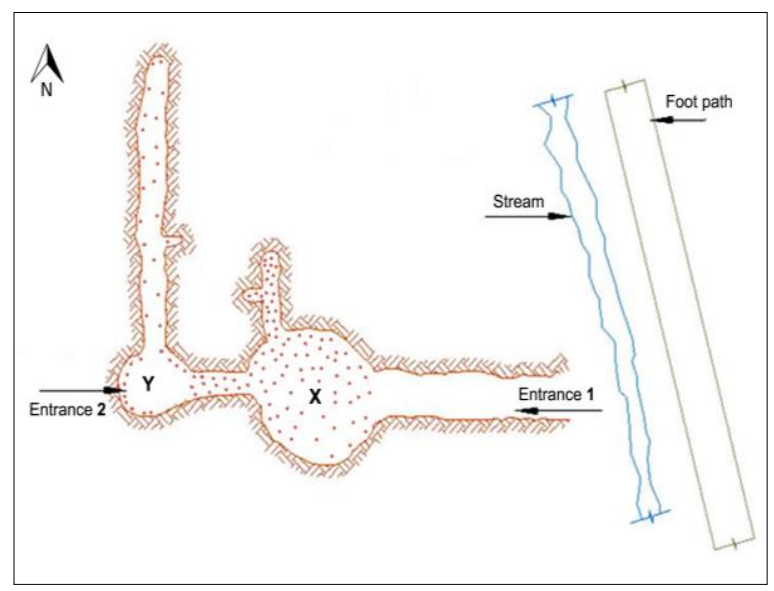

Figure 2. Cross section of the floor plan of the mine in study site A from aerial view (not to scale); dotted area shows the area occupied by bats; $\mathrm{X}$ and $\mathrm{Y}$ indicate the localities of microclimatic data recorded.

Entrance 2 (alt. $135 \mathrm{~m}$ a.s.1.) was a $11.2 \mathrm{~m}$ deep vertical hole with a $4.1 \times 2.6 \mathrm{~m}$ sized opening (Figs. 3B-C), located on the hilly side of the plantation, about $15 \mathrm{~m}$ behind Entrance 1 . The canopy cover around Entrance 2 was 30 $40 \%$ and mainly consisted of old rubber trees (maximum height $11 \mathrm{~m}$ ). At the time of observation $(11: 39 \mathrm{~h})$ ambient air temperature was $28.9{ }^{\circ} \mathrm{C}\left(\min 25.9{ }^{\circ} \mathrm{C}\right.$, max $\left.28.9{ }^{\circ} \mathrm{C}\right)$ and relative humidity was $85 \%$ ( $\min 79 \%$, max $88 \%$ ), velocity of wind was recorded as 0.75 $\mathrm{km} / \mathrm{h}$ and the light intensity was 19288.9 lux.

Social calls of the bats were audible by half way through the tunnel from Entrance 1. Sympatric roosting behaviour of $R$. rouxii (Fig. 6) and H. speoris (Fig. 7) was evident and most of the ceilings and vertical walls of the mine, except the tunnel area, were occupied by $>2000$ bats. About 5\% (100 individuals) of the bats were $H$. speoris and the remainder were $R$. rouxii. Body temperature of roosting $R$. rouxii ( $n=3$ ) ranged between $23.9-24.8^{\circ} \mathrm{C}$ and $H$. speoris $(n=2)$ was 24.1 and $24.6^{\circ} \mathrm{C}$. Microclimatic conditions recorded at two places ( $\mathrm{X}$ and $\mathrm{Y}$ in Fig. 2) inside study site $\mathrm{A}$ are given in Table 3. The morphometric variables and morphological characteristics of the specimens found in study site A are given in Tables 1, 2, and 5 . 
Table 1. Morphometric variables for Rhinolophus rouxii from study site A (Hapitigama) and site B (Hapitigamkanda), Gampaha District, Sri Lanka with a comparison to Phillips (1935) and Bates \& Harrison (1997); measurements in mm; — not available.

\begin{tabular}{|c|c|c|c|c|c|c|c|}
\hline \multirow{3}{*}{ Measurements } & \multicolumn{4}{|c|}{ This study } & \multirow{2}{*}{\multicolumn{2}{|c|}{$\begin{array}{c}\text { Philips } \\
\text { (1935) }\end{array}$}} & \multirow{3}{*}{$\begin{array}{c}\text { Bates \& } \\
\text { Harrison (1997) } \\
\text { Male \& Female } \\
(n=\text { unknown) }\end{array}$} \\
\hline & \multicolumn{2}{|c|}{ site $A$} & \multicolumn{2}{|c|}{ site $B$} & & & \\
\hline & $\begin{array}{c}\text { Female } \\
(n=1)\end{array}$ & $\begin{array}{c}\text { Female } \\
(n=1)\end{array}$ & $\begin{array}{l}\text { Male } \\
(\mathrm{n}=1)\end{array}$ & $\begin{array}{c}\text { Female } \\
(\mathrm{n}=1)\end{array}$ & $\begin{array}{c}\text { Male } \\
(n=41)\end{array}$ & $\begin{array}{l}\text { Female } \\
(n=26)\end{array}$ & \\
\hline head and body length & 50.2 & 53.6 & 48.76 & 52.51 & $54.2-60.0$ & $53.1-60.0$ & $47.0-60.0$ \\
\hline ear length & 17.6 & 17.5 & 14.51 & 17.22 & $20.0-22.0$ & $19.1-22.0$ & $14.0-22.0$ \\
\hline ear width & 10.6 & 11.2 & 12.41 & 12.1 & - & - & - \\
\hline forearm length & 49.5 & 47.3 & 48.16 & 49.47 & $48.3-51.0$ & $47.0-54.0$ & $44.0-49.0$ \\
\hline wingspan length & 330 & 320 & 320 & 310 & $298-324$ & $286-317$ & $288-304$ \\
\hline $3^{\text {rd }}$ metacarpal & 40.5 & 37.7 & 36.84 & 39.98 & - & - & $34.0-39.0$ \\
\hline tail length & 22.1 & 18.9 & 20.19 & 23.45 & $25.7-30.0$ & $27.1-30.0$ & $20.0-30.0$ \\
\hline tibia length & 23.4 & 21.7 & 22.03 & 23.67 & - & - & $19.0-23.0$ \\
\hline hind foot length & 10.1 & 9.7 & 8.82 & 9.91 & $9.1-11.0$ & $9.1-12.0$ & $8.0-11.0$ \\
\hline calcar length & 12.8 & 12.2 & 13.13 & 13.77 & - & - & - \\
\hline body weight (g) & 13.3 & 11.2 & 11.72 & 12.79 & - & - & - \\
\hline
\end{tabular}

Table 2. Morphometric variables for Hipposideros speoris from study site A at Hapitigama, Gampaha District, Sri Lanka with a comparison to Phillips (1935) and Bates \& Harrison (1997); measurements in mm; — not available.

\begin{tabular}{|c|c|c|c|c|c|}
\hline \multirow{2}{*}{ Measurements } & \multicolumn{2}{|c|}{$\begin{array}{c}\text { This study } \\
\text { site A }\end{array}$} & \multicolumn{2}{|c|}{$\begin{array}{l}\text { Philips } \\
(1935)\end{array}$} & \multirow{2}{*}{$\begin{array}{c}\text { Bates \& } \\
\text { Harrison (1997) } \\
\begin{array}{c}\text { Male \& Female } \\
(n=\text { unknown })\end{array}\end{array}$} \\
\hline & $\begin{array}{l}\text { Male } \\
(n=1)\end{array}$ & $\begin{array}{l}\text { Male } \\
(n=1)\end{array}$ & $\begin{array}{c}\text { Male } \\
(n=11)\end{array}$ & $\begin{array}{l}\text { Female } \\
(n=22)\end{array}$ & \\
\hline head and body length & 56.7 & 59.2 & $55.0-56.0$ & $55.0-60.0$ & $46.0-62.0$ \\
\hline ear length & 15.1 & 15.0 & $16.1-18.0$ & $17.1-20.0$ & $12.0-19.0$ \\
\hline ear width & 12.6 & 12.5 & - & - & - \\
\hline forearm length & 54.8 & 52.1 & $52.0-54.0$ & $52.0-54.0$ & $45.6-54.0$ \\
\hline wingspan length & 340 & 340 & $311-324$ & $314-324$ & - \\
\hline $3^{\text {rd }}$ metacarpal & 43.0 & 41.5 & - & - & $35.0-42.0$ \\
\hline tail length & 24.3 & 17.8 & $24.0-30.0$ & $25.0-30.0$ & $20.0-29.0$ \\
\hline tibia length & 22.2 & 22.1 & - & - & $18.0-23.3$ \\
\hline hind foot length & 8.8 & 8.21 & $8.0-9.0$ & $8.0-9.0$ & $7.0-11.0$ \\
\hline calcar length & 16.0 & 13.5 & - & - & - \\
\hline body weight (g) & 15.0 & 11.6 & - & - & - \\
\hline
\end{tabular}

Table 3. Microclimatic conditions recorded at two places from study site A (X and Y, Fig. 2) and two places at site B (P and Q; Fig. 4) inside the mines at Hapitigama and Hapitigamkanda (Gampaha District), respectively

\begin{tabular}{|c|c|c|c|c|}
\hline \multirow{2}{*}{ Microclimatic condition } & \multicolumn{2}{|c|}{ site A } & \multicolumn{2}{|c|}{ site $\mathrm{B}$} \\
\hline & $\mathrm{X}$ & Y & $\mathrm{P}$ & Q \\
\hline temperature ${ }^{\circ} \mathrm{C}$ & 26.2 & 27.2 & 27.2 & 26.9 \\
\hline$(\min , \max )$ inside mines & $(25.9,27.0)$ & $(25.9,28.9)$ & $(25.9,26.0)$ & $(25.9,36.9)$ \\
\hline humidity \% & 85 & 86 & 89 & 85 \\
\hline$(\min , \max )$ & $(79,87)$ & $(79,87)$ & $(86,89)$ & $(76,88)$ \\
\hline $\begin{array}{l}\text { temperature }\left({ }^{\circ} \mathrm{C}\right) \\
\text { outside mines }\end{array}$ & $24-25$ & 24.1 & 23.3 & 25.1 \\
\hline velocity of Wind $(\mathrm{Km} / \mathrm{h})$ & 0 & 0 & 0 & 0 \\
\hline light Intensity (lux) & 1932.1 & 1808.3 & 796.5 & 2368.1 \\
\hline
\end{tabular}



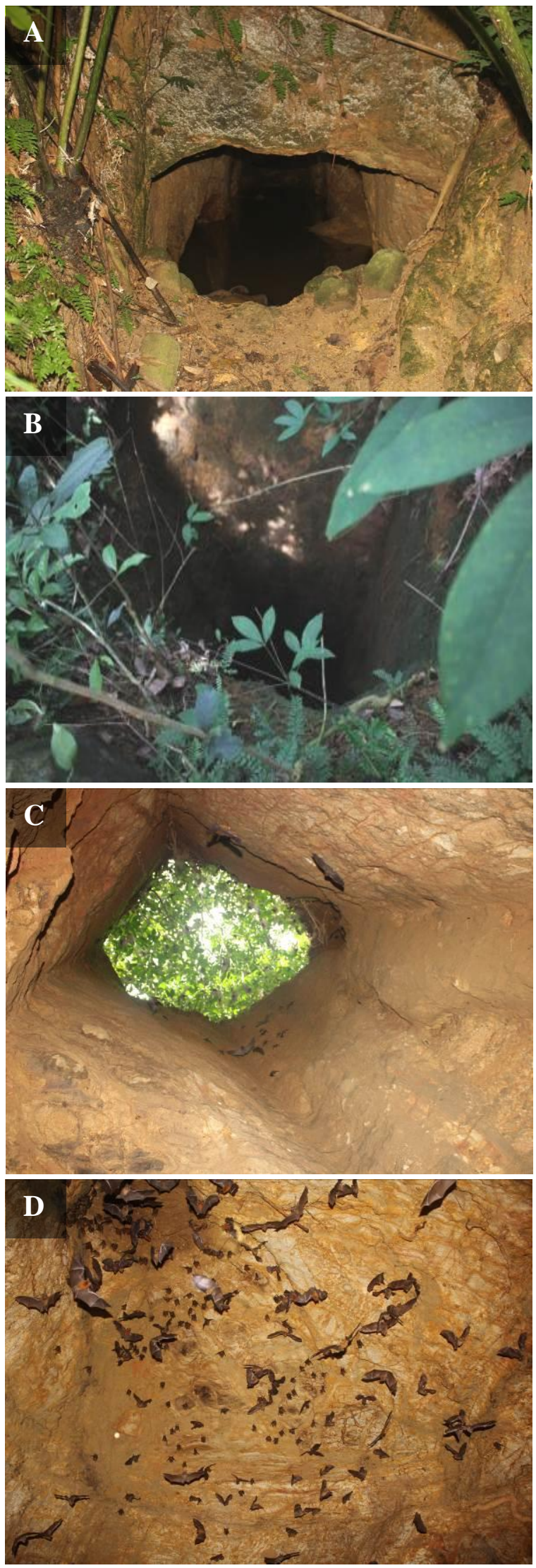

Figure 3. Entrance habitat of mine in site $A$ at Hapitigama, Gampaha District, Sri Lanka; outside views of (A) Entrance 1 and (B) Entrance 2; (C) inside view of Entrance 1; (D) main chamber at $\mathrm{X}$
Study site B: $\left(7^{\circ} 11^{\prime} 54.3^{\prime \prime} \mathrm{N} 80^{\circ} 07^{\prime} 43.4^{\prime \prime} \mathrm{E}\right.$; alt.192 $\mathrm{m}$ a.s.l.) a mine located in a secondary forest patch with minimal current anthropogenic disturbance. There were two prominent entrances (Fig. 4) about $10 \mathrm{~m}$ apart and several other smaller points of entry. Canopy cover near the entrances was $75 \%$ (maximum height about $6 \mathrm{~m})$ dominated by Honduran mahogany (Swietenia macrophylla), Ceylon breadfruit (Artocarpus nobilis), and Cane (Calamus rotang). At the time of observation (14:56 h) ambient air temperature near the entrances was $27.8{ }^{\circ} \mathrm{C}\left(\min 25.9{ }^{\circ} \mathrm{C}\right.$, $\left.\max 36{ }^{\circ} \mathrm{C}\right)$ and relative humidity was $82 \%(\min 76 \%, \max 89 \%)$. Velocity of wind was recorded as $0 \mathrm{~km} / \mathrm{h}$ and the light intensity was 12690.6 lux. Entrances were vertical tunnels measuring $2.8 \times 2.8 \times 8.5 \mathrm{~m}$ (Entrance 1; Fig. 5A) and $3.6 \times 3.3 \times 13.2 \mathrm{~m}$ (Entrance 2; Fig. 5C-D) (length $\times$ width $\times$ depth) at the opening. Compared to site A, site B had a complicated structure with several lateral and downward passages that either open to large chambers or end blindly. Microclimatic conditions recorded at two places ( $\mathrm{P}$ and $\mathrm{Q}$ in Fig. 4) inside study site $\mathrm{B}$ is given in Table 3

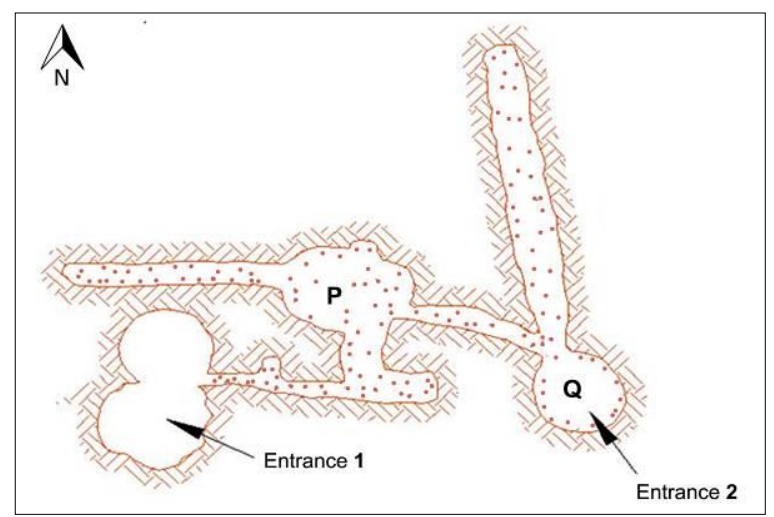

Figure 4. Cross section of the floor plan of the mine in study site B from aerial view (not for scale); dotted area shows the area occupied by bats; $\mathrm{P}$ and $\mathrm{Q}$ indicate the localities of microclimatic data recorded.

Our calculation estimated around $1,500+R$. rouxii individuals. However, the actual population size could be much more because many chambers were difficult to approach for counting. There was no evidence of $H$. speoris roosting in this mine. $R$. rouxii occupied almost all the ceilings and vertical walls except the chamber near Entrance 1 (Fig. 4). The body temperature of $R$. rouxii at site $\mathrm{B}$ ranged from $24.1-24.6{ }^{\circ} \mathrm{C}(n=3)$. The morphometric variables and morphological characteristics of the specimens found in study site B are given in Tables 1 and 5. 

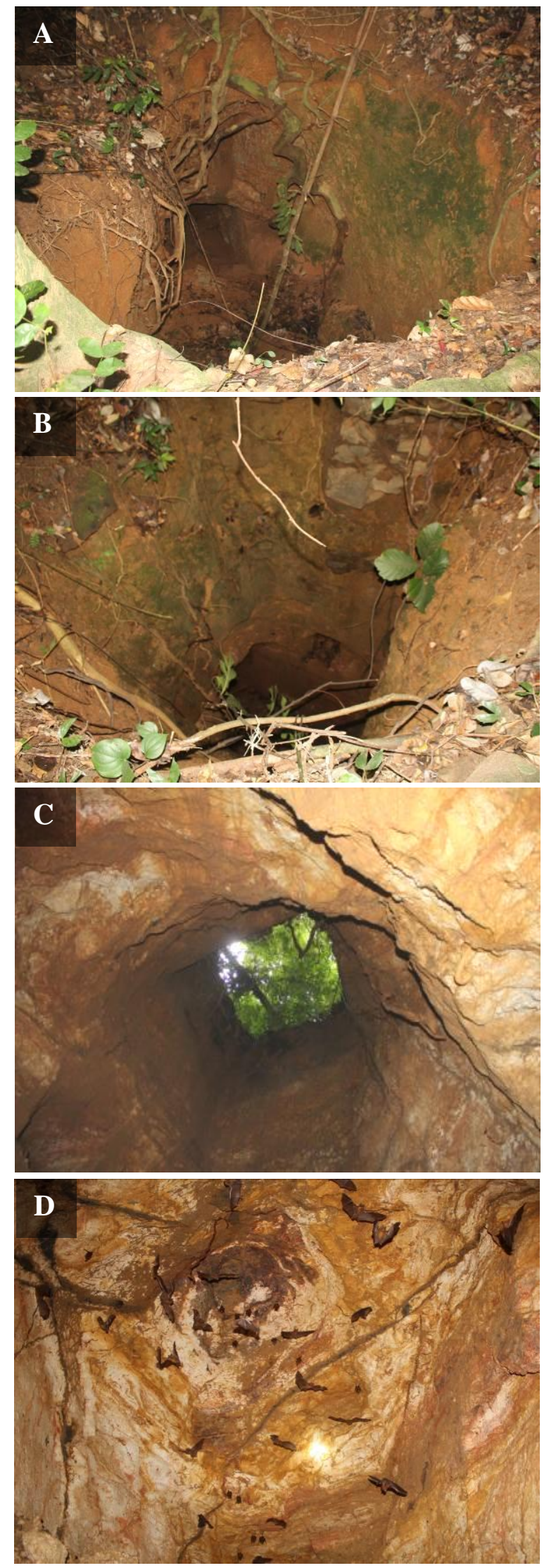

Figure 5. Entrance habitat of mine in site $B$ at Hapitigamkanda, Gampaha District, Sri Lanka; outside views of (A) Entrance 1 and (B) Entrance 2; (C) inside view of Entrance 2; (D) main chamber at $\mathrm{P}$
Historical records indicate that $R$. rouxii had been found commonly in the low country in Sri Lanka up to an altitude of 1,371 m (Fig. 1) and occasionally at higher elevations of $1,829 \mathrm{~m}$ in West Haputale (Philips 1935). There are more recent records of frequent occurrence in Radella, Udupussellawa and Idalgashinna up to an elevation of 1,590 m (Kusuminda et al. 2020). They roost in either small or very large colonies in caves, graphite mines, culverts, old houses, wells, temples and hollow trees in primary habitats of moist evergreen, lowland forests (Phillips 1935, Bates \& Harrison 1997, Molur et al. 2002, Yapa 2017, Kusuminda et al. 2013, Kusuminda et al. 2018, Wilson \& Mittermeier 2019). Hipposideros speoris had also been recorded throughout the low country in Sri Lanka up to an elevation of $1,385 \mathrm{~m}$ (Fig. 1). They roost, singly, in pairs, and in small or large groups in small crevices, caves, tunnels, temples, graphite mines, and abandoned buildings in primary habitats of dry plains to forested hill sides (Phillips 1935, Bates \& Harrison 1997, Molur et al. 2002, Kusuminda et al. 2013, Yapa 2017, Kusuminda et al. 2018, Wilson \& Mittermeier 2019). Limited literature is available relating to the distribution and population size of $R$. rouxii and $H$. speoris in the Western Province of Sri Lanka. Kusuminda et al. (2013) observed both $R$. rouxii and H. speoris in the Pilikuttuwa ancient cave temple, which is approximately $17.5 \mathrm{~km}$ from the present study sites. But fewer individuals ( $R$. rouxii $=1, H$. speoris $=25$ ) were recorded during a 14-month study (February 2011-April 2012), and there was no evidence of permanent roosting sites for $R$. rouxii (Kusuminda et al. 2013).

Hence, our observations are new site records for $R$. rouxii and $H$. speoris and also represent the two largest documented colonies of $R$. rouxii in the Western province of Sri Lanka. Present observations on both roosting sites and habitat associations agree with the previous autecological reports. Observations on sympatric behavior between $R$. rouxii and $H$. speoris are also in accordance with previous literature (See Fig 1). According to the existing literature $R$. rouxii has two prominent breeding cycles from April to May and from September to November with gestation periods lasting for 150-160 days (Phillips 1935, Bates \& Harrison 1997, Yapa 2017, Wilson \& Mittermeier 2019). Occurrence of pregnant females from site $\mathrm{B}$ indicates that the breeding season of this colony occurs during April to May. 


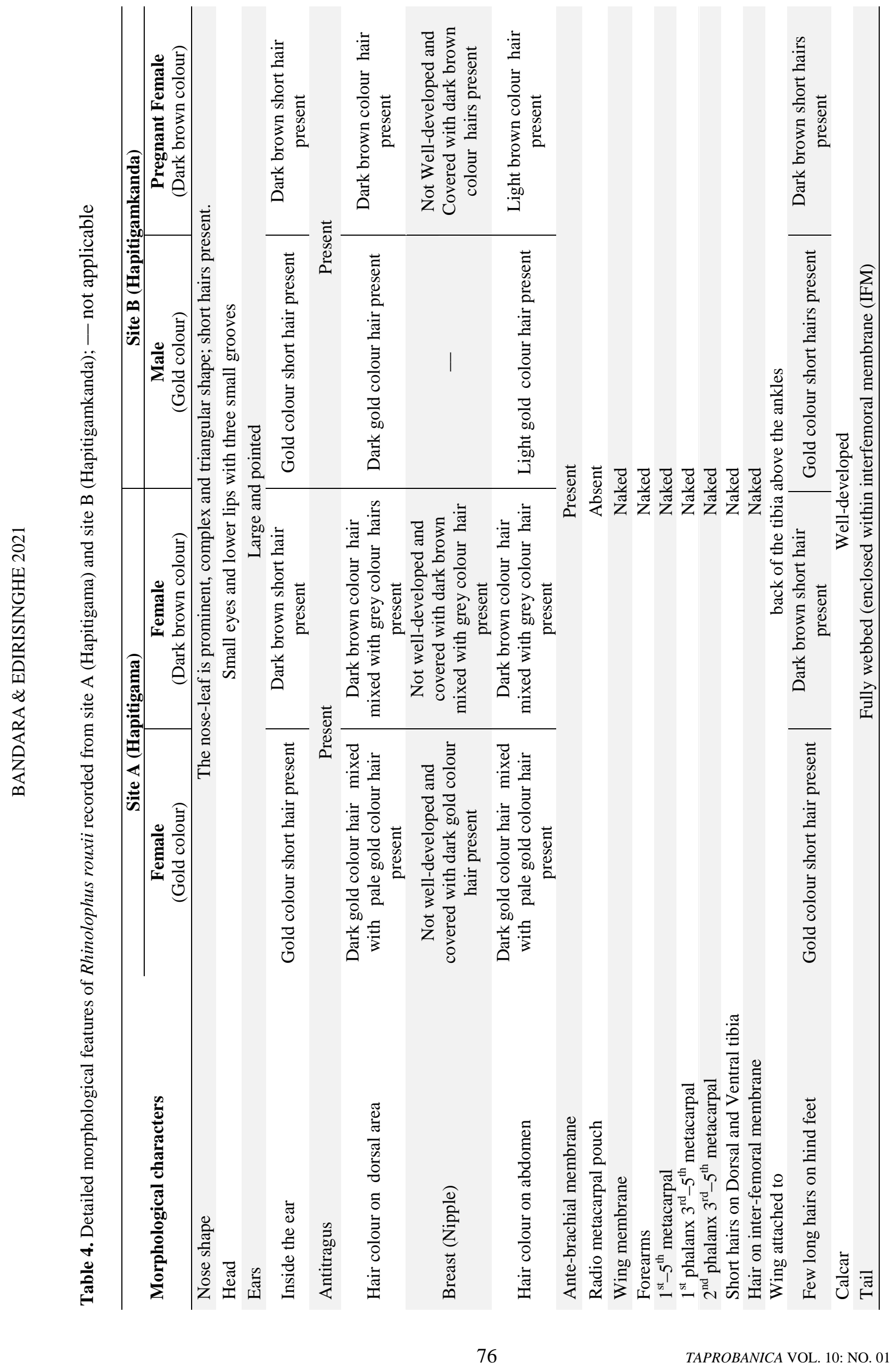




\section{Plate 16}

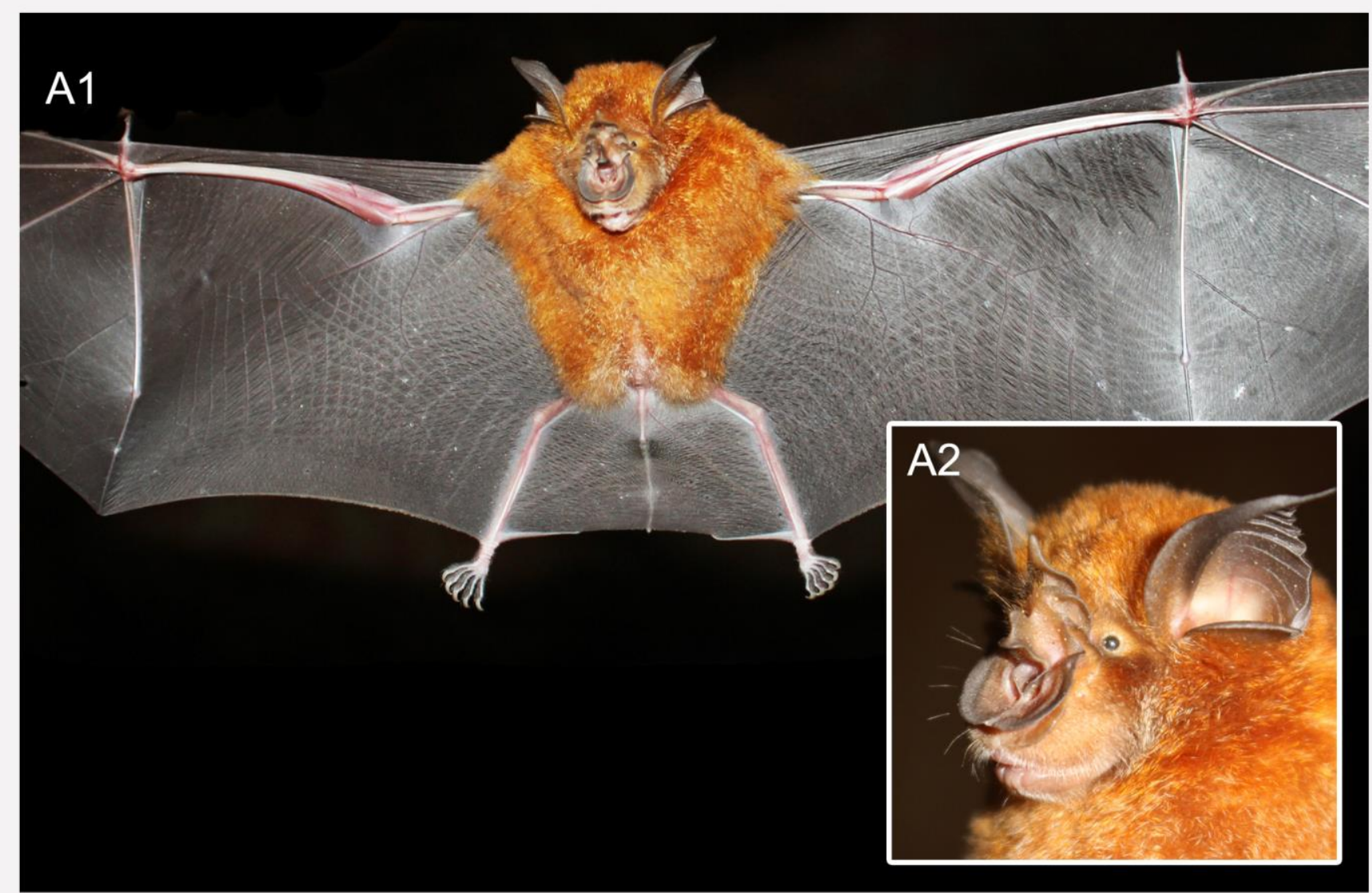

Figure 6. A Rhinolophus rouxii individual (female) from site A (Hapitigama, Gampaha District, Sri Lanka): (A1) ventral aspect of expanded wings, (A2) facial structure. Photo (C A.P. Malsha J. Bandara

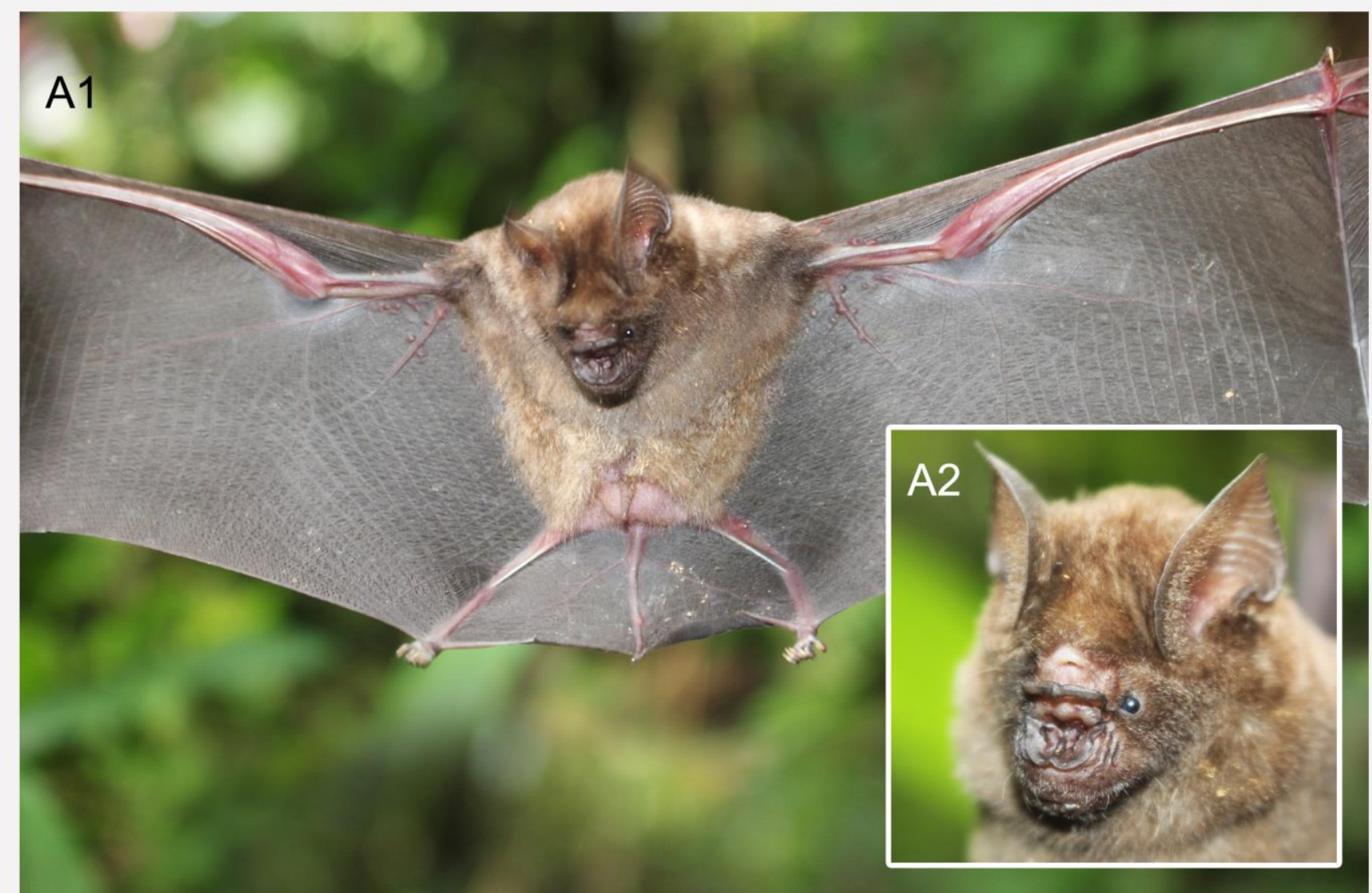

Figure 7. A Hipposideros speoris individual (male) from site A (Hapitigama, Gampaha District, Sri Lanka): (A1) ventral aspect of expanded wings, (A2) facial structure. Photo (C) A.P. Malsha J. Bandara 
Table 5. Detailed morphological features of Hipposideros speoris recorded from site A at Hapitigama, Gampaha District, Western province, Sri Lanka; — not applicable

\begin{tabular}{|c|c|c|}
\hline Morphological characters & $\begin{array}{c}\text { Male } \\
\text { (Dark brownish grey colour) }\end{array}$ & $\begin{array}{c}\text { Male } \\
\text { (Dark blackish grey colour) }\end{array}$ \\
\hline Nose shape & \multicolumn{2}{|c|}{ The Nose-leaf, is Prominent complex and Square shape } \\
\hline Head & \multirow{2}{*}{\multicolumn{2}{|c|}{$\begin{array}{c}\text { Small eyes, Three small Supplementary leaf lets present } \\
\text { Well-developed }\end{array}$}} \\
\hline Frontal sac & & \\
\hline Ears & \multicolumn{2}{|c|}{ Rather small, with rounded tips } \\
\hline Inside the ear & Grey colour short hairs present & $\begin{array}{c}\text { Dark blackish grey short hairs } \\
\text { present }\end{array}$ \\
\hline Antitragus & \multicolumn{2}{|c|}{$\begin{array}{c}\text { Conspicuous Spine like projection about one third from the making the } \\
\text { antitragus present }\end{array}$} \\
\hline Hair colour on dorsal area & $\begin{array}{l}\text { Dark brownish grey colour hairs } \\
\text { present }\end{array}$ & $\begin{array}{c}\text { Dark brownish grey colour hairs } \\
\text { present }\end{array}$ \\
\hline Hair colour on chest & Brownish grey colour hairs present & $\begin{array}{c}\text { Dark blackish grey colour hairs } \\
\text { present }\end{array}$ \\
\hline Hair colour on abdomen & $\begin{array}{l}\text { Light Brownish grey colour hairs } \\
\text { present }\end{array}$ & $\begin{array}{l}\text { Light blackish grey colour hairs } \\
\text { present }\end{array}$ \\
\hline Ante-brachial membrane & \multicolumn{2}{|c|}{ Present } \\
\hline Radio metacarpal pouch & \multicolumn{2}{|c|}{ Absent } \\
\hline Wing membrane & \multicolumn{2}{|c|}{ Naked } \\
\hline Forearms & \multicolumn{2}{|c|}{ Naked } \\
\hline $1^{\text {st }}-5^{\text {th }}$ metacarpal & \multicolumn{2}{|c|}{ Naked } \\
\hline $1^{\text {st }}$ phalanx $3^{\text {rd }}-5^{\text {th }}$ metacarpal & \multicolumn{2}{|c|}{ Naked } \\
\hline $2^{\text {nd }}$ phalanx $3^{\text {rd }}-5^{\text {th }}$ metacarpal & \multicolumn{2}{|c|}{ Naked } \\
\hline $\begin{array}{l}\text { Short hairs on Dorsal and } \\
\text { Ventral tibia }\end{array}$ & \multicolumn{2}{|c|}{ Naked } \\
\hline $\begin{array}{l}\text { Hair on inter-femoral } \\
\text { membrane (dorsal \& ventral) }\end{array}$ & \multicolumn{2}{|c|}{ Naked } \\
\hline Wing attached to & \multicolumn{2}{|c|}{ the tibia just above the Ankles } \\
\hline Few hairs on hind feet & Brown colour short hairs present & Brownish grey short hairs present \\
\hline Calcar & \multicolumn{2}{|c|}{ Well-developed } \\
\hline Tail & \multicolumn{2}{|c|}{ Fully webbed (enclosed with Inter-femoral membrane (IFM) } \\
\hline
\end{tabular}

Even though study site B had a more complicated structure and less anthropogenic pressure, the population size of site $A$ was higher and $H$. speoris was absent at site $\mathrm{B}$. Proximity to water bodies could be a reason for the larger population size and the presence of $H$. speoris at site A. Of all types of roosting places, caves provide the most stable conditions for bats, allowing them to colonize in large numbers (Yapa 2017). Similar to caves, abandoned graphite mines also play a vital role in the life of tropical bats, by maintaining stable microclimatic conditions, which is important for breeding and raising pups (Yapa \& Ratnasooriya 2008, Yapa 2017). Humidity of the two study sites was relatively high (85-89\%), which is preferred by $R$. rouxii (Wilson \& Mittermeier 2019) and the ambient temperature of the roosts was also less than the outside temperature. Yapa \& Ratnasooriya (2008) further state that there is a close relationship between the roost type and the colony size with large colonies found in caves. Hence, it is important to conserve roosting places, especially abandoned graphite mines that help to sustain large populations of bats. Based on the discussions we had with locals, these mine-dwelling bats are frequently hunted as a cheap source of meat using thorny branches. Digana et al. (2000) have recorded that a whole population of Hipposiderous lankadiva in Bogala mine has disappeared due to human hunting. This is a common threat to bats in Sri Lanka and in the whole Asian region (Mildenstein et al. 2016, Yapa 2017, Dar et al. 2018). Therefore, it is important to educate the locals in order to minimize the killing of bats (Digana et al. 2000). Colony sizes of bats have drastically declined over the past few years due to deforestation, roost destruction and human interaction (Yapa 2017, Mouler 2002). Priority conservation attention should be given to Sri Lankan bats regardless of their global conservation status. Establishing baseline data by carrying out systematic field surveys in unexplored areas will play an important role for conserving bat fauna in the island (Lim 2017). 


\section{Acknowledgement}

We thank W. Bandara for arranging the field visits, officers of Mirigama police station and several villagers including S. Pushpakumara, G. Bandara, A.R.C. Kumara, and N. Madushan for their invaluable support rendered to us during our field visit. Also, we thank P. Disanayake for the sketches of the study sites and $\mathrm{S}$. Karunarathna for the assistance.

\section{Literature cited}

Bates, P.J.J. and D.L. Harrison (1997). Bats of the Indian Subcontinent. Harrison Zoological Museum, Kent: 258pp.

Borissenko, A.V. and S.V. Kruskop (2003). Bats of Vietnam and Adjacent Territories: an identification manual. Zoological Museum of Moscow M. V. Lomonosov State University, Moscow: $211 \mathrm{pp}$.

Corbet, G.B. and J.E. Hill (1992). The mammals of the Indomalayan Region: a systematic review. Natural History Museum Publications, Oxford University Press: 488pp.

Dar, T.H., M. Kamalakannan, C. Venkataraman, and K. Chandra (2018). New record of Hipposideros speoris (Chiroptera: Hipposideridae) from Myanmar hidden in the national zoological collection of the Zoological Survey of India. Mammalia, 83 (5): 515-517.

Digana, P.M.C.B., W.B. Yapa, P.V. Randeniya, and W.D. Ratnasooriya (2000). Predators of Sri Lankan bats. Loris, 22: 44-48.

Gunatileke, I.A.U.N. and C.V.S. Gunatileke (1990). Distribution of floristic richness and its conservation in Sri Lanka. Conservation Biology, 4 (1): 21-31.

IUCN-MOE (2012). The National Red List 2012 of Sri Lanka: Conservation Status of the Fauna and Flora. Ministry of Environment, Colombo, Sri Lanka: 476pp.

Kusuminda, T.G.T., W.G.M. Edirisinghe, R.P. Nanayakkara, and N. Vishvanath (2013). Diversity and population status of bats in Pilikuttuwa ancient cave temple in Gampaha District, Sri Lanka. Asian Journal of Conservation Biology, 2 (2): 136-143.

Kusuminda, T.G.T., A. Mannakkara, B.D. Patterson, and W.B. Yapa (2018). Bats in tea plantations in Sri Lanka: Species richness and distribution. Journal of Bat Research \& Conservation, 11 (1): 96-105.

Lim, B.K. (2017). High diversity but low profile: new initiatives in the study of bats in Sri Lanka. Loris, 28 (1\&2): 21-24.

Mildenstein, T., I. Tanshi, and P.A. Racey (2016). Exploitation of bats for bushmeat and medicine. In: Voigt C. and T. Kingston (eds.). Bats in the Anthropocene: Conservation of Bats in a Changing World. Springer, Cham: 325-376pp.

Molur, S., G. Marimuthu, C. Srinivasulu, S. Mistry et al. (eds.) (2002). Status of South Asian Chiroptera: Conservation Assessment and Management Plan (C.A.M.P.) Workshop Report, 2002. Zoo Outreach Organisation, CBSG South Asia and WILD, Coimbatore: 320pp.

Phillips, W.W.A. (1935). A Manual of the Mammals of Ceylon. Dulau \& Company, London: 373pp.

Srinivasulu, C., P.A. Racey, and S. Mistry (2010). A key to the bats (Mammalia: Chiroptera) of South Asia. Journal of Threatened Taxa, 2 (7): 1001-1076.

Thomas, D.W. and R.K. Laval (1988). Survey and census methods. In: Kunz, T.H. (ed.). Ecological and Behavioral Methods for the Study of Bats. Smithsonian Institution Press, Washington DC: 77-89pp.

Thomas, D.W., M.B. Fenton, and R.M.R. Barclay (1979). Social behavior of the little brown bat, Myotis lucifugus I. mating behavior. Behavioral Ecology \& Sociobiology, 6: 129136.

Wilson, D.E. and R.A. Mittermeier (eds.) (2019). Handbook of the Mammals of the World. Vol. 9: Bats. Lynx Editions, Barcelona: 1008pp.

Yapa, W. (2017). A Field Guide to the Bats of Sri Lanka. Dilmah Ceylon Tea Company PLC, Colombo, Sri Lanka: 142pp.

Yapa, W.B. and W.D. Ratnasooriya (2008). Ecology and Biology of Sri Lankan Bats. University of Colombo: 28pp.

Yapa, A. and G. Ratnavira (2013). The Mammals of Sri Lanka. Field Ornithology Group of Sri Lanka, University of Colombo, Colombo, Sri Lanka: 1009pp.

Yapa, W.B., W.D. Ratnasooriya, H.H. Costa, and R. Ruebsamen (2005). In flight and out flight activity patterns of five species of cave dwelling bats in Sri Lanka. Journal of Science of the University of Kelaniya, 2: 41-62.

Submitted: 9 April 2021, Accepted: 10 May 2021 Section Editor: Burton Lim

\section{A.P.M.J. Bandara ${ }^{1} \&$ G. Edirisinghe ${ }^{2}$}

${ }^{I}$ No 153/3, Parakandeniya, Imbulgoda, Sri Lanka E-mail: malshabandara83@gmail.com

${ }^{2}$ Biodiversity Conservation Society, No 150/6, Stanley Thilakaratne Mawatha, Nugegoda 10250, Sri Lanka 